\title{
ANALISIS PROFITABILITAS USAHATANI BAWANG MERAH BERDASARKAN MUSIM DI TIGA KABUPATEN SENTRA PRODUKSI DI INDONESIA
}

\author{
Haris F. Aldila ${ }^{1)}$, Anna Fariyanti ${ }^{2)}$, dan Netti Tinaprilla ${ }^{2)}$ \\ ${ }^{1)}$ Mahasiswa Pascasarjana Magister Sains Agribisnis, FEM, Institut Pertanian Bogor \\ ${ }^{2)}$ Staf Pengajar Departemen Agribisnis, FEM, Institut Pertanian Bogor \\ E-mail: harisfatori@gmail.com
}

\begin{abstract}
The objectives of this research are (1) to analyze the characteristics of farmers and the performance of shallot farming and (2) to analyze the profitability of shallot farming in production centers in Java. The research was conducted in Cirebon, Brebes, and Tegal regency with the number of respondents each of 40 farmers. Farm profitability level indicated by $R / C$ ratio in every season (rainy season, first dry season and second dry season) during 2013/2014. The results showed that shallot farming in Cirebon, Brebes, and Tegal feasible and profitable to cultivate in every season. Farmers in Cirebon had the biggest gain in the second dry season of Rp 47 million per hectare with $R / C$ of 1.65. Farmers in Brebes had the biggest gain in the first dry season amounted to Rp 23 million per hectare with $R / C$ of 1.42 . Farmers in Tegal had the biggest gain in the rainy season of $R p 31$ million per hectare with $R / C$ of 1.48 .
\end{abstract}

Keyword : profitability, shallot, Cirebon, Brebes, Tegal

\begin{abstract}
Abstrak : Tujuan penelitian mengenai analisis profitabilitas usahatani bawang merah ini adalah (1) melihat karakteristik petani dan keragaan usahatani bawang merah, (2) menganalisis tingkat profitabilitas usahatani bawang merah di tiga kabupaten sentra produksi di Pulau Jawa. Lokasi penelitian yang dipilih yaitu Kabupaten Cirebon, Brebes, dan Tegal dengan jumlah responden petani masing-masing 40 petani. Tingkat profitabilitas usahatani ditunjukkan dengan pendekatan nilai rasio $\mathrm{R} / \mathrm{C}$ pada setiap musim (MH, MK I dan MK II) pada musim tanam tahun 2013/2014. Hasil penelitian menunjukkan bahwa usahatani bawang merah di Kabupaten Cirebon, Brebes, dan Tegal layak dan menguntungkan untuk diusahakan pada setiap musim. Petani di Kabupaten Cirebon memperoleh keuntungan terbesar pada musim kemarau II sebesar Rp 47 juta per hektar dengan R/C sebesar 1,65. Petani di Kabupaten Brebes memperoleh keuntungan terbesar pada musim kemarau I sebesar Rp 23 juta per hektar dengan R/C sebesar 1,42. Petani di Kabupaten Tegal memperoleh keuntungan terbesar pada musim hujan sebesar Rp 31 juta per hektar dengan R/C sebesar 1,48.
\end{abstract}

Kata kunci : Profitabilitas, Bawang merah, Cirebon, Brebes, Tegal

\section{PENDAHULUAN}

Bawang merah merupakan salah satu komoditas strategis dan penting bagi perekonomian di Indonesia. Usahatani bawang merah merupakan sumber pendapatan dan kesempatan kerja yang memberikan kontribusi cukup tinggi terhadap perkembangan ekonomi wilayah (Deptan 2005). Hal ini tidak terlepas dari status bawang merah sebagai komoditas hortikultura bernilai tinggi (high value comodity). Usahatani bawang merah mampu mendatangkan keuntungan yang jauh lebih besar jika dibandingkan dengan usahatani pada komoditas pangan seperti padi atau jagung. Menurut Dinas Pertanian Kabupaten Bandung (2006) yang dikutip dalam Natawidjaja (2007) menunjukkan bahwa petani memperoleh 
pendapatan dari usahatani padi sawah $\mathrm{Rp}$ 6,6 juta/ha/musim dan jagung $\mathrm{Rp} 4,5$ juta/ha/musim. Sedangkan petani yang mengusahakan bawang merah memperoleh pendapatan mencapai Rp $40 \mathrm{juta} / \mathrm{ha} / \mathrm{musim}$.

Walaupun bawang merah merupakan salah satu komoditas bernilai tinggi yang mampu mendatangkan keuntungan yang besar bagi petani, kondisi saat ini menunjukkan produksi bawang merah dalam negeri belum sepenuhnya dapat memenuhi kebutuhan dalam negeri. Selama periode tahun 2008-2012 Indonesia masih menjadi net importer bawang merah. Indonesia mengimpor bawang merah dari beberapa negara di antaranya Thailand, Vietnam, India, Filipina, Malaysia dan Cina. Ketidakstabilan produksi menyebabkan pasokan bawang merah bervariasi antar waktu sehingga pada saat-saat tertentu Indonesia masih mengimpor bawang merah. Hal ini dikarenakan bawang merah merupakan tanaman musiman yang hanya ditanam pada musim-musim tertentu. Perkembangan ekspor impor bawang merah di Indonesia selama tahun 2008-2012 dapat dilihat pada Tabel 1.

Musim tanam bawang merah di Indonesia banyak dilakukan pada musim kemarau. Penanaman bawang merah baru akan dilakukan pada musim kemarau I setelah Padi dan musim kemarau II (Maryowani dan Darwis 2010; Winarso 2003; Purmiyati 2002). Musim tanam bawang merah yang pertama biasanya bulan April-Mei. Tanaman kedua dan ketiga dilakukan bulan Juli-Agustus dan Oktober-
November (Purmiyati 2002). Produksi bawang merah pada musim hujan jarang dilakukan karena adanya kendala berupa terganggunya proses fotositesis dan serangan penyakit yang menyebabkan produksi menurun sehingga petani lebih memilih untuk menanam padi (Purba dan Astuti 2013). Hal tersebut yang meyebabkan terjadinya kelangkaan pasokan bawang merah sehingga Indonesia mengimpor bawang merah pada periode tertentu terutama pada musim hujan. Menurut Sayaka dan Supriatna (2010), bawang merah impor biasanya masuk pada bulan Januari-April. Pada bulan tersebut, produksi bawang merah dalam negeri menurun karena bertepatan dengan musim hujan. Impor bawang merah pada bulanbulan tersebut tidak hanya untuk konsumsi tetapi juga untuk benih karena terjadi kelangkaan benih pula pada musim hujan (Putrasamedja 2010). Pengaruh musim tidak hanya berdampak pada adanya fluktuasi produksi tetapi juga menyebabkan adanya fluktuasi harga. Sifat produk bawang merah yang mudah rusak (perishable) menyebabkan harga cenderung fluktuatif dan perubahan harga yang sangat cepat (Asmara dan Ardhiani 2010). Harga bawang merah sangat berfluktuasi tergantung dengan kondisi pasar. Fluktuasi harga sangat tergantung terhadap permintaan dan penawaran bawang merah. Selama tiga tahun terakhir (2012-2014), harga bawang merah tertinggi terjadi pada bulan Agustus 2013 yaitu mencapai Rp 60.768/kg.

Tabel 1. Perkembangan Ekspor-Impor Bawang Merah Tahun 2008-2012

\begin{tabular}{lrrrrr}
\hline \multirow{2}{*}{ Keterangan } & \multicolumn{5}{c}{ Tahun } \\
\cline { 2 - 6 } Ekspor & $\mathbf{2 0 0 8}$ & $\mathbf{2 0 0 9}$ & $\mathbf{2 0 1 0}$ & $\mathbf{2 0 1 1}$ & $\mathbf{2 0 1 2}$ \\
$\quad$ Volume (Ton) & 12.314 & 12.822 & 3.234 & 13.792 & 18.754 \\
$\quad$ Nilai (000 US\$) & 4.534 & 4.348 & 1.814 & 6.594 & 8.552 \\
Impor & & & & & \\
$\quad$ Volume (Ton) & 128.015 & 67.330 & 73.270 & 160.467 & 120.354 \\
$\quad$ Nilai (000 US\$) & 53.814 & 28.942 & 33.862 & 77.444 & 53.615 \\
Neraca & & & & & \\
$\quad$ Volume (Ton) & -115.701 & -54.508 & -70.036 & -146.675 & -101.600 \\
$\quad$ Nilai (000 US\$) & -49.280 & -24.594 & -32.048 & -70.850 & -45.063 \\
\hline S
\end{tabular}

Sumber : BPS, diolah Pusdatin (Pusdatin, 2013) 
Sedangkan harga eceran rata-ratanya hanya berkisar antara $\mathrm{Rp} 10.000-15.000 / \mathrm{kg}$ (Kemendag 2015). Tingginya harga bawang ini dikarenakan adanya permintaan yang sangat tinggi karena bertepatan dengan hari raya idul fitri dan adanya kenaikan harga bahan bakar minyak (BBM). Permintaan yang tinggi tidak diimbangi dengan pasokan yang cukup sehingga menyebabkan harga bawang merah meningkat tajam.

Fluktuasi produksi dan harga akan berpengaruh terhadap pendapatan usahatani petani bawang merah. Pendapatan petani dari usahatani bawang merah dapat bervariasi antar musim tanam. Hal ini dikarenakan adanya pengaruh musim terhadap produksi dan harga bawang merah mengingat bawang merah merupakan tanaman musiman yang hanya ditanam pada musim-musim tertentu. Oleh karena itu perlu dilakukan penelitian yang mengkaji bagaimana karakteristik dan keragaan usahatani bawang merah dan komparasi profitabilitas usahatani bawang merah berdasarkan musim di daerah sentra produksi di Indonesia.

\section{METODE PENELITIAN}

Penelitian dilaksanakan di tiga kabupaten sentra produksi yang terletak di provinsi Jawa Tengah dan Jawa Barat. Pemilihan lokasi dilakukan secara purposive. Sentra produksi bawang merah di Jawa Tengah yang dipilih adalah Kabupaten Brebes, dan Kabupaten Tegal. Sentra produksi di Jawa Barat yang dipilih adalah Kabupaten Cirebon.

Data yang digunakan dalam penelitian ini merupakan data sekunder yang diperoleh dari data penelitian tematik bawang merah Pusat Kajian Hortikultura Tropika (PKHT) IPB tahun 2014. Pengumpulan data yang dilakukan oleh PKHT dilakukan melalui metode survei dan wawancara langsung dengan responden petani bawang merah dengan bantuan kuesioner. Responden petani bawang merah ditentukan secara purposive. Jumlah data responden yang digunakan dalam penelitian ini sebanyak 40 petani bawang merah di masing-masing kabupaten sehingga total responden sebanyak 120 petani bawang merah.

Metode analisis data yang digunakan dalam penelitian ini adalah analisis deskriptif kualitatif dan analisis kuantitatif. Analisis deskriptif kualitatif digunakan untuk mendeskripsikan gambaran umum mengenai karakteristik petani bawang merah di lokasi penelitian. Analisis kuantitatif digunakan untuk menganalisis profitabilitas usahatani bawang merah.

Profitabilias dalam penelitian ini didefinisikan sebagai selisih antara penerimaan usahatani dengan biaya tunai usahatani atau biaya yang secara aktual dikeluarkan oleh petani. Penerimaan usahatani berasal dari penjualan umbi bawang merah untuk konsumsi. Biaya yang dikeluarkan petani meliputi biaya benih, biaya pupuk, biaya obat-obatan, upah tenaga kerja, iuran irigasi, biaya pengairan, pajak lahan, sewa lahan, dan biaya lain yang terkait.

Dalam penelitian ini juga dihitung rasio penerimaan dengan pengeluaran (R/C) usahatani bawang merah untuk menentukan kelayakan usahatani bawang merah di lokasi penelitian. Secara matematis dirumuskan sebagai berikut:

$\mathrm{TR}=\mathrm{Py} . \mathrm{Y}$

$\mathrm{TC}=\mathrm{FC}+\mathrm{VC}$

$\pi=\mathrm{TR}-\mathrm{TC}$

$\mathrm{R} / \mathrm{C}=(\mathrm{Py} . \mathrm{Y}) /(\mathrm{FC}+\mathrm{VC})$

Keterangan:

$\mathrm{TR}=$ Total Penerimaan

$\mathrm{TC}=$ Total Biaya

$\pi=$ Profitabilitas

Py = Harga output

$\mathrm{Y}=$ Jumlah output

$\mathrm{FC}=$ Biaya tetap (fixed cost)

$\mathrm{VC}=$ Biaya variabel (variable cost)

Jika:

a. R/C > 1 maka usaha layak dilaksanakan

b. $\mathrm{R} / \mathrm{C}<1$ maka usaha tidak layak dilaksanakan

c. $\mathrm{R} / \mathrm{C}=1$ maka usaha impas (tidak untung maupun rugi)

\section{HASIL DAN PEMBAHASAN}

\section{Karakteristik Petani Bawang Merah}

Karakteristik dari masing-masing petani berbeda-beda dan dapat mempengaruhi keragaan usahatani dari aspek teknik budidaya sehingga akan berpengaruh juga terhadap produksi yang dihasilkan. Karakteristik petani 
responden yang dianggap penting untuk diketahui diantaranya umur, tingkat pendidikan, status usahatani, pengalaman bertani, status kepemilikan lahan, luas lahan dan pola tanam.

Tabel 2 menunjukkan bahwa sebagian besar petani berada dalam kisaran umur 40-59 tahun. Sebaran umur petani di Kabupaten Cirebon dan Brebes relatif sama yaitu paling banyak pada rentang usia 40-49 tahun, sedangkan di Kabupaten Tegal sebaran umur petani terbesar pada kisaran umur 50-59 tahun. Hasil tersebut menunjukkan bahwa usahatani bawang merah di Kabupaten Cirebon dan Brebes masih dilakukan oleh petani pada usia produktif. Usia produktif adalah usia yang paling tepat untuk menjalankan aktifitasaktifitas bekerja seperti bertani karena secara fisik masih baik, memiliki semangat tinggi dan adanya kewajiban untuk menghidupi keluarga. Sementara itu, petani di Kabupaten Tegal ternyata sudah melewati masa produktif karena sebagian besar petani berusia di atas 50 tahun.

Dilihat dari tingkat pendidikan formal, pendidikan petani sangat beragam mulai dari sekolah dasar (SD) sampai lulusan perguruan tinggi. Akan tetapi masih ditemui petani yang tidak menyelesaikan masa studi sekolah dasarnya, bahkan ada yang tidak sekolah sama sekali. Petani dengan pendidikan sekolah dasar relatif lebih banyak jumlahnya di Kabupaten Cirebon dan Tegal. Sementara itu, di Kabupaten Brebes petani didominasi oleh petani dengan tingkat pendidikan sekolah menengah atas (SMA). Tingkat pendidikan akan mempengaruhi cara berpikir petani dan tingkat penyerapan teknologi dan ilmu pengetahuan.

Tabel 2. Karakteristik Petani Bawang Merah di Kabupaten Cirebon, Brebes dan Tegal

\begin{tabular}{|c|c|c|c|c|c|c|c|}
\hline \multirow[b]{2}{*}{ No } & \multirow[b]{2}{*}{ Uraian } & \multicolumn{2}{|c|}{ Cirebon } & \multicolumn{2}{|c|}{ Brebes } & \multicolumn{2}{|c|}{ Tegal } \\
\hline & & $\begin{array}{l}\text { Jumlah } \\
\text { (orang) }\end{array}$ & $\begin{array}{c}\text { Persentase } \\
(\%)\end{array}$ & $\begin{array}{l}\text { Jumlah } \\
\text { (orang) }\end{array}$ & $\begin{array}{c}\text { Persentase } \\
(\%)\end{array}$ & $\begin{array}{l}\text { Jumlah } \\
\text { (orang) }\end{array}$ & $\begin{array}{c}\text { Persentase } \\
(\%)\end{array}$ \\
\hline \multirow[t]{5}{*}{1.} & Umur (tahun) & & & & & & \\
\hline & a. $30-39$ & 5 & 12,5 & 11 & 27,5 & 7 & 17,5 \\
\hline & b. $40-49$ & 16 & 40 & 21 & 52,5 & 12 & 30 \\
\hline & c. $50-59$ & 12 & 30 & 3 & 7,5 & 15 & 37,5 \\
\hline & d. $>60$ & 7 & 17,5 & 5 & 12,5 & 6 & 15 \\
\hline \multirow[t]{7}{*}{2.} & Tingkat Pendidikan & & & & & & \\
\hline & a. Tidak Sekolah & 3 & 7,5 & 1 & 2,5 & 2 & 5 \\
\hline & b. Tidak Tamat SD & 11 & 27,5 & 7 & 17,5 & 2 & 5 \\
\hline & c. SD & 14 & 35 & 11 & 27,5 & 14 & 35 \\
\hline & d. SMP & 8 & 20 & 4 & 10 & 10 & 25 \\
\hline & e. SMA & 2 & 5 & 15 & 37,5 & 9 & 22,5 \\
\hline & f. Perguruan Tinggi & 2 & 5 & 2 & 5 & 3 & 7,5 \\
\hline \multirow[t]{5}{*}{3.} & Pengalaman Bertani (tahun) & & & & & & \\
\hline & a. $1-10$ & 15 & 37,5 & 6 & 15 & 13 & 32,5 \\
\hline & b. $11-20$ & 12 & 30 & 15 & 37,5 & 11 & 27,5 \\
\hline & c. $21-30$ & 11 & 27,5 & 15 & 37,5 & 7 & 17,5 \\
\hline & d. $>30$ & 2 & 5 & 4 & 10 & 9 & 22,5 \\
\hline \multirow[t]{5}{*}{4.} & Status Kepemilikan Lahan & & & & & & \\
\hline & a. Milik Sendiri & 6 & 15 & 22 & 55 & 21 & 52,5 \\
\hline & b. Sewa & 32 & 80 & 14 & 35 & 16 & 40 \\
\hline & c. Campuran & 2 & 5 & 1 & 2,5 & 3 & 7,5 \\
\hline & d. Bagi Hasil & - & - & 3 & 7,5 & - & - \\
\hline \multirow[t]{6}{*}{5.} & Luas Lahan (Ha) & & & & & & \\
\hline & a. $<0,10$ & - & - & 5 & 12,5 & - & - \\
\hline & b. $0,10-0,24$ & 5 & 12,5 & 11 & 27,5 & 11 & 27,5 \\
\hline & c. $0,25-0,49$ & 17 & 42,5 & 12 & 30 & 14 & 35 \\
\hline & d. $0,50-1,00$ & 5 & 12,5 & 9 & 22,5 & 14 & 35 \\
\hline & e. $>1$ & 13 & 32,5 & 3 & 7,5 & 1 & 2,5 \\
\hline
\end{tabular}

Sumber : PKHT, 2014 (Diolah) 


\section{Haris F. A., Anna F., dan Netti T.: Analisis profitabilitas usahatani ...}

Pengalaman bertani petani bawang merah di Kabupaten Brebes relatif lebih lama daripada petani di Kabupaten Cirebon dan Tegal. Pengalaman petani bawang merah di Kabupaten Brebes dalam melakukan usahatani bawang merah antara 11-30 tahun sedangkan di Kabupaten Cirebon dan Tegal sebagian besar berkisar antara 1-10 tahun. Usahatani bawang merah di Kabupaten Brebes relatif lebih lama dikembangkan sehingga banyak petani yang sudah lama membudidayakan bawang merah baik secara mandiri maupun dari usaha turun temurun orang tua.

Penguasaan lahan untuk budidaya bawang merah relatif kecil yaitu masih dibawah satu hektar. Sebagian besar petani di Kabupaten Cirebon, Brebes dan Tegal mengusahakan bawang merah pada lahan dibawah 0,5 hektar. Status kepemilikan lahan didominasi oleh lahan milik sendiri untuk di Kabupaten Brebes dan Tegal. Sementara itu, di Kabupaten Cirebon didominasi oleh lahan sewa. Biaya sewa lahan di ketiga lokasi penelitian bervariasi. Rata-rata sewa lahan per tahun di Kabupaten Cirebon sebesar Rp 14.000.000/ha, di Kabupaten Brebes Rp 12.000.000/ha, dan di Kabupaten Tegal Rp 11.000.000/ha. Keseluruhan lahan yang dimiliki petani responden di tiga lokasi penelitian merupakan lahan sawah dengan irigasi konvensional dan semi teknis.

\section{Keragaan Usahatani Bawang Merah}

Budidaya bawang merah yang dilakukan oleh petani di tiga lokasi penelitian sebagian besar dilakukan secara monokultur. Akan tetapi, ada beberapa petani yang juga melakukan tumpangsari dengan tanaman lain seperti cabai atau terong. Dalam satu tahun, rata-rata petani menanam bawang merah 2-3 kali dalam setahun karena umur panennya yang singkat yaitu 55-60 hari. Penanaman bawang merah di ketiga lokasi penelitian banyak dilakukan di daerah dataran rendah. Menurut Putrasamedja (2010), ketinggian lokasi penanaman bawang merah yang ideal berkisar antara 4-300 meter diatas permukaan laut. Pada ketinggian ini, produksi yang dihasilkan bisa optimum dan umur panennya lebih genjah. Di Kabupaten Tegal, budidaya bawang merah dilakukan tidak hanya di daerah dataran rendah tetapi juga pada lahan dataran tinggi. Di dataran tinggi umur panen bawang merah lebih lama yaitu 90 hari. Petani di dataran tinggi membudidayakan bawang merah hanya satu kali dalam satu tahun. Hal ini dikarenakan petani juga menanam sayuran lain seperti kubis, bawang daun, cabai, dan sebagainya.

Petani mempertimbangkan ketersediaan air dalam melakukan penanaman bawang merah karena bawang merah merupakan tanaman yang membutuhkan banyak air. Petani di lokasi penelitian menanam bawang merah pada musim hujan dan musim kemarau I dimana pada musim ini ketersediaan air melimpah. Namun sebagian besar petani menanam pada musim kemarau I karena pada musim hujan petani lebih memilih menanam padi. Beberapa petani juga menanam pada musim kemarau II apabila air untuk irigasi cukup tersedia. Pada saat musim kemarau, apabila tidak terdapat air irigasi, petani masih bisa menanam bawang merah dengan menggunakan irigasi dari sumur pompa yang dibuat oleh petani. Jika ketersediaan air irigasi tidak memadai maka lahan tersebut tidak ditanami bawang merah. Petani akan menanaminya dengan tanaman jagung atau membiarkan bera sampai musim hujan tiba. Tanaman bawang merah merupakan tanaman hortikultura yang sangat peka terhadap hujan dan kekeringan (Widyantara dan Yasa 2013).

Petani menanam bawang merah pada bulan Oktober/November, April/Mei, dan Juni/Juli, dimana pada bulan-bulan ini intensitas hujan tidak tinggi. Menurut Purba (2014), penanaman pada bulan Juli-September merupakan waktu yang terbaik yang dapat memberikan hasil optimal bawang merah, sedangkan penanaman pada bulan Januari-Februari merupakan musim terburuk. Secara umum pola tanam yang ditemukan di tiga lokasi penelitian hampir sama yaitu sebagai berikut:

1. Bawang Merah - Bawang Merah - Bawang Merah - Jagung

2. Padi - Bawang Merah - Bawang Merah - Bera Produksi bawang merah yang diusahakan petani bervariasi antar daerah dan antar musim (Tabel 3). Kabupaten Cirebon memiliki produktivitas bawang merah yang lebih besar dibandingkan dengan Kabupaten Brebes dan Tegal. Kabupaten Brebes memiliki produktivitas bawang merah terendah dibandingkan dengan kabupaten lainnya. Produktivitas bawang merah di Kabupaten Cirebon berkisar antara 11,3-14,1 ton/ha. Produktivitas bawang merah di Kabupaten Brebes berkisar antara 8,2-8,8 ton/ha sedang di Kabupaten Tegal produktivitasnya lebih tinggi yaitu berkisar antara 8,7-9,8 ton/ha. Rendahnya produktivitas bawang merah di Kab. Brebes diduga karena intensitas penanaman 
Haris F. A., Anna F., dan Netti T.: Analisis profitabilitas usahatani ...

Tabel 3. Produktivitas Bawang Merah Per Musim di Kabupaten Cirebon, Brebes, dan Tegal Musim Tanam Tahun 2013-2014

\begin{tabular}{lccc}
\hline \multirow{2}{*}{ Kabupaten } & \multicolumn{3}{c}{ Produktivitas (Ton/ha) } \\
\cline { 2 - 4 } & MH & MK I & MK II \\
\hline Cirebon & 11,3 & 13,2 & 14,1 \\
Brebes & 8,2 & 8,9 & 8,8 \\
Tegal & 8,7 & 9,4 & 9,8 \\
\hline
\end{tabular}

Sumber : PKHT, 2014 (Diolah)

bawang merah yang relatif lebih sering dibanding kabupaten lain. Tingginya intensitas penanaman bawang merah pada lahan yang sama menyebabkan kesuburan lahan berkurang karena budidaya bawang merah juga intensif dalam penggunaan pupuk dan obat-obatan kimia.

Dilihat berdasarkan musim, produktivitas bawang merah terbesar terjadi pada musim kemarau. Di Kabupaten Cirebon dan Tegal, produktivitas tertinggi dicapai pada musim kemarau II yaitu sebesar 14,1 ton/ha untuk Kabupaten Cirebon dan 9,8 ton/ha untuk Kabupaten Tegal. Sementara itu, produktivitas tertinggi di Kabupaten Brebes dicapai pada musim kemarau I dengan produktivitas sebesar 8,9 ton/ha. Produktivitas bawang merah terendah di ketiga lokasi penelitian dicapai pada musim hujan. Pada musim hujan, bawang merah banyak terkena penyakit yaitu layu daun dengan gejala daun bawang merah layu secara tiba-tiba setelah terkena air hujan. Menurut petani penyakit ini sangat sering menyerang ketika musim hujan dan belum ada alternatif cara mengatasinya. Hal ini yang menyebabkan produksi bawang merah pada musim penghujan menurun. Hasil panen bawang merah yang dihasilkan oleh petani sebagian besar dijual sebagai bawang merah konsumsi. Diantara hasil produksi tersebut, petani juga menyisihkan sebagian hasil panen untuk dijadikan benih pada musim tanam selanjutnya. Rata-rata petani di Kabupaten Cirebon menyisihkan 19 persen hasil panennya untuk disimpan menjadi benih, petani di Kabupaten Brebes menyisihkan 28 persen dan petani di Kabupaten Tegal menyisihkan 38 persen.

Benih yang digunakan berupa umbi bawang merah yang sudah mengalami penyimpanan selama 2 bulan. Petani membutuhkan benih bawang merah rata-rata sebanyak 1,64 ton/ha. Menurut Dinas Pertanian Tanaman Pangan dan Hortikultura Kabupaten Brebes (2011), jumlah kebutuhan bawang merah per hektar mencapai 1,5 ton. Jumlah kebutuhan benih ini bervariasi tergantung dengan besar kecilnya umbi bawang merah yang digunakan untuk benih.

Petani bawang merah di Kabupaten Brebes dan Tegal menggunakan benih seluruhnya dari varietas lokal. Petani di Kabupaten Brebes menggunakan benih lokal varietas Bima Brebes. Petani di Kabupaten Tegal menggunakan varietas Bima Brebes dan varietas Sumenep. Varietas Bima Brebes banyak digunakan petani bawang merah di dataran rendah, sedangkan varietas Sumenep banyak digunakan petani bawang merah di dataran tinggi. Petani di Kabupaten Cirebon menggunakan benih varietas lokal dan juga benih impor. Benih varietas lokal yang digunakan adalah varietas Bima Brebes dan verietas Timur. Varietas Bima Brebes relatif lebih banyak digunakan oleh petani dibandingkan varietas Timur. Sementara itu, benih impor yang digunakan petani adalah varietas Ilocost dan Super Philip.

Penggunaan benih impor saat ini sudah sangat jarang dilakukan oleh petani di Kabupaten Cirebon yang menggunakan benih impor karena ketersediaan benih impor terbatas dan pemasarannya pun juga terbatas. Selain itu, petani juga lebih menyukai bawang merah lokal daripada impor karena bawang merah lokal lebih mudah dalam pemasarannya dan lebih disukai oleh masyrakat karena memiliki aroma dan rasa yang lebih baik daripada bawang merah impor. Hal tersebut senada dengan hasil penelitian Basuki (2009a) yang menyebutkan bahwa dalam hal daya hasil, jumlah anakan, bentuk umbi, ukuran umbi, warna umbi, dan aroma varietas lokal (Bima Brebes) lebih disukai petani dibanding varietas impor. Selain itu, varietas lokal (Bima Brebes) lebih mudah dijual atau dipasarkan, dapat dibibitkan lagi, dan dapat ditanam pada musim kemarau maupun hujan.

Sumber benih varietas lokal yang digunakan petani sebagian besar berasal dari benih yang dihasilkan petani sendiri dari penanaman sebelumnya. Ada pula beberapa petani yang membeli ke petani lain. Menurut Basuki (2010), 
benih hasil produksi petani kualitasnya cukup baik yang tercermin dari daya tumbuh $(99,1 \%)$, tingkat infeksi oleh penyakit tular benih $(1,7 \%)$, dan persentase kemurnian varietas $(99,3 \%)$. Banyaknya petani yang memproduksi sendiri benih bawang merah disebabkan oleh harga benih yang sangat mahal, pembuatan benih tidaklah sulit serta produksinya tidak berbeda jauh dari benih yang baru (Darwis et al 2004).

Petani menggunakan pupuk organik maupun kimia dalam budidaya bawang merah. Pupuk organik yang digunakan petani berasal dari pupuk organik pabrikan. Rata-rata penggunaan pupuk organik ini sebesar 1,3 ton/ha. Petani lebih banyak menggunakan pupuk organik pabrikan daripada pupuk kandang. Hal ini dikarenakan kemudahan dalam memperoleh pupuk organik tersebut. Pupuk organik sangat mudah diperoleh karena tersedia di kios-kios pupuk.

Penggunaan pupuk kimia pada budidaya bawang merah di tiga lokasi penelitian juga cukup beragam. Menurut Dinas Pertanian Tanaman Pangan dan Hortikultura Kabupaten Brebes (2011) dalam budidaya bawang merah diperlukan pupuk diantaranya SP36/TSP sebanyak $300 \mathrm{~kg} / \mathrm{ha}, \mathrm{KCl}$ sebanyak $120 \mathrm{~kg} / \mathrm{ha}$, Urea sebanyak $120 \mathrm{~kg} / \mathrm{ha}$, ZA sebanyak 220 $\mathrm{kg} / \mathrm{ha}$, Kamas sebanyak $120 \mathrm{~kg} / \mathrm{ha}$, dan NPK DAP sebanyak $200 \mathrm{~kg} / \mathrm{ha}$. Hasil penelitian (Tabel 4) menunjukkan petani menggunakan pupuk urea, $\mathrm{KCl}$ dan NPK DAP lebih dari anjuran yang disarankan. Sementara itu, petani menggunakan pupuk SP36/TSP, ZA dan Kamas masih dibawah dosis anjuran menurut Dinas Pertanian Tanaman Pangan dan Hortikultura Kabupaten Brebes (2011). Pemupukan sebagian besar dilakukan sebanyak 3 kali yaitu pada 10 , 20, dan 30 hari setelah tanam.

Obat-obatan atau pestisida yang digunakan oleh petani terdiri dari insektisida, fungisida, dan herbisida. Insektisida banyak digunakan pada musim kemarau karena pada musim ini serangan hama seperti ulat relatif lebih banyak. Penggunaan insektisida pada usahatani bawang merah masih dilakukan secara intensif di ketiga lokasi penelitian. Penyemprotan insektisida mulai dilakukan pada 10 hari setelah tanam dengan frekuensi penyemprotan dua atau tiga hari sekali. Penyemprotan akan terus dilakukan sampai bawang merah menjelang panen. Hal ini dilakukan petani untuk mencegah serangan ulat daun yang banyak menyerang tanaman bawang merah. Penggunaan insektisida yang intensif ini dipicu karena adanya resistensi pada hama ulat yang menyerang bawang merah sehingga penggunaan insektisida dilakukan secara berlebihan (Moekasan dan Basuki 2007). Selain itu menurut Basuki (2009b), petani bawang merah juga memiliki keterbatasan pengetahuan dalam mengenali pestisida yang sesuai untuk pengendalian hama ulat sehingga penggunaan pestisida sangat beragam.

Budidaya bawang merah masih sangat membutuhkan banyak tenaga kerja manusia dari proses pengolahan lahan sampai pemanenan. Kebutuhan tenaga kerja ini diperoleh dari tenaga kerja dalam keluarga dan tenaga kerja di luar keluarga. Tenaga kerja dalam keluarga digunakan pada kegiatan pemeliharaan seperti penyemprotan, penyiangan, penyiraman, dan pemupukan. Sementara itu tenaga kerja untuk kegiatan pengolahan lahan, penanaman, dan pemanenan lebih banyak menggunakan tenaga kerja dari luar. Kegiatan pengolahan lahan sampai siap tanam dikerjakan dengan dengan menggunakan sistem upah harian atau sistem borongan. Rata-rata kebutuhan tenaga kerja usahatani bawang merah di Brebes 390 HOK, di Cirebon 246 HOK, dan di Tegal 234 HOK.

Tabel 4. Jumlah Penggunan Pupuk pada Budidaya Bawang Merah di Kabupaten Cirebon, Brebes dan Tegal Musim Tanam Tahun 2013-2014

\begin{tabular}{lcccccccccc}
\hline \multirow{2}{*}{ Jenis Pupuk } & \multirow{2}{*}{ Satuan } & \multicolumn{3}{c}{ Cirebon } & \multicolumn{3}{c}{ Brebes } & \multicolumn{3}{c}{ Tegal } \\
\cline { 3 - 11 } & & MH & MK I & MK II & MH & MK I & MK II & MH & MK I & MK II \\
\hline Pupuk Organik & $\mathrm{Kg} / \mathrm{Ha}$ & 1.300 & 1.072 & 1.128 & 1.278 & 798 & 889 & 1.783 & 1.818 & 1.669 \\
Urea & $\mathrm{Kg} / \mathrm{Ha}$ & 148 & 160 & 165 & 165 & 169 & 173 & 158 & 229 & 250 \\
$\mathrm{TSP}$ & $\mathrm{Kg} / \mathrm{Ha}$ & 219 & 240 & 212 & 202 & 248 & 218 & 297 & 276 & 249 \\
$\mathrm{KCl}$ & $\mathrm{Kg} / \mathrm{Ha}$ & 190 & 184 & 184 & 174 & 195 & 205 & 115 & 104 & 121 \\
$\mathrm{ZA}$ & $\mathrm{Kg} / \mathrm{Ha}$ & 154 & 176 & 189 & 304 & 211 & 121 & 228 & 259 & 216 \\
DAB & $\mathrm{Kg} / \mathrm{Ha}$ & 202 & 253 & 141 & 155 & 157 & 132 & 234 & 249 & 285 \\
Kamas & $\mathrm{Kg} / \mathrm{Ha}$ & 161 & 136 & 141 & 143 & 156 & 174 & 154 & 149 & 138 \\
\hline
\end{tabular}

Sumber : PKHT, 2014 (Diolah) 
Jam kerja untuk buruh tani baik pria maupun wanita di ketiga lokasi penelitian adalah 5 jam per hari dimulai dari jam 7 pagi sampai jam 12 siang. Upah tenaga kerja di Kabupaten Cirebon dan Brebes relatif sama. Upah tenaga kerja pria rata-rata $\mathrm{Rp}$ 50.000/hari, sedangkan untuk tenaga kerja wanita $\mathrm{Rp}$ 30.000/hari. Petani biasanya juga mengeluarkan biaya konsumsi untuk tenaga kerja sebesar Rp 5.000/orang per hari.

Di Kabupaten Tegal, upah tenaga kerja untuk buruh tani daerah dataran rendah berbeda dengan upah buruh tani di dataran tinggi. Upah buruh tani daerah dtaran tinggi relatif lebih murah. Upah tenaga kerja buruh tani untuk daerah dataran rendah rata-rata $\mathrm{Rp} 45.000$ 50.000/hari untuk pria dan $\mathrm{Rp} 30.000$ 35.000/hari untuk wanita. Sementara itu, upah tenaga kerja buruh tani untuk daerah dataran tinggi rata-rata $\mathrm{Rp} 20.000$ - 25.000/hari untuk pria dan Rp 15.000 - 20.000/hari untuk wanita.

\section{Profitabilitas Usahatani Bawang Merah}

Dua komponen penting dalam menghitung profitabilitas usahatani bawang merah adalah penerimaan dan biaya usahatani bawang merah. Dalam penelitian ini, komponen biaya yang dihitung merupakan biaya yang benar-benar dikeluarkan oleh petani (biaya tunai). Biaya usahatani tersebut dikelompokkan menjadi tiga yaitu: (a) biaya sarana produksi, (b) biaya tenaga kerja dan (c) biaya lainnya. Biaya sarana produksi terdiri dari biaya untuk pembelian benih, pupuk, dan obat-obatan. Biaya tenaga kerja merupakan jumlah upah yang dibayarkan terhadap penggunaan tenaga kerja di luar keluarga baik berupa uang tunai maupun natura. Biaya lain-lain mencakup biaya iuran irigasi, biaya bahan bakar mesin pompa, biaya sewa lahan, pajak tanah dan biaya lain yang terkait. Komponen biaya dalam usahatani bawang merah di Kabupaten Cirebon, Brebes dan Tegal dapat dilihat pada Tabel 5 .

Dari Tabel 5 dapat dilihat bahwa pengeluaran biaya usahatani bawang merah di ketiga lokasi bervariasi. Pengeluaran usahatani di Kabupaten Cirebon relatif lebih tinggi jika dibandingkan dengan Kabupaten Brebes maupun Tegal. Rata-rata biaya usahatani yang dikeluarkan sebesar Rp 71.134.283/ha. Sementara itu, rata-rata biaya usahatani yang dikeluarkan di Kabupaten Brebes sebesar Rp 56.918.272/ha dan di Kabupaten Tegal sebesar Rp 55.675.310/ha. Tingginya biaya usahatani di Kabupaten Cirebon salah satunya dipengaruhi oleh tingginya harga benih bawang merah. Harga benih bawang merah di Kabupaten Cirebon relatif lebih mahal jika dibandingkan dengan Kabupaten Brebes atau Tegal. Rata-rata harga benih bawang merah di Kabupaten Cirebon Rp $18.750 / \mathrm{kg}$, di Kabupaten Brebes Rp 16.020/kg dan di Kabupaten Tegal Rp 17.019/kg.

Pengeluaran terbesar usahatani bawang merah di Kabupaten Cirebon terjadi pada musim kemarau II. Hal ini dikarenakan pengeluaran untuk tenaga kerja di luar keluarga dan biaya bahan bakar untuk pengairan pompa lebih tinggi dibandingkan musim lainnya. Sementara itu, di Kabupaten Brebes dan Tegal, pengeluaran usahatani terbesar terjadi pada musim hujan. Hal ini bisa terjadi karena di kedua lokasi tersebut pengeluaran untuk benih pada musim hujan cenderung lebih besar dibandingkan musim lainnya. Harga benih pada musim kemarau cenderung lebih mahal jika dibandingkan dengan musim lainnya. Selain itu, kebutuhan tenaga kerja luar keluarga juga meningkat terutama untuk kegiatan perawatan sehingga pengeluaran untuk tenaga kerja relatif besar.

Komponen pengeluaran terbesar dalam usahatani bawang merah adalah untuk sarana produksi berkisar antara 51,19-63,80 persen. Dari komponen biaya sarana produksi ini, pembelian benih merupakan komponen pengeluaran yang paling besar. Dilihat berdasarkan pengeluaran total maka pengeluaran untuk benih berkisar antara 27,46-44,36 persen dengan rata-rata sebesar 37,80 persen. Selain biaya pembelian benih, upah tenaga kerja juga menjadi komponen pengeluaran terbesar dalam usahatani bawang merah. Pengeluaran untuk upah tenaga kerja berkisar antara 31,75-41,91 persen dengan rata-rata sebesar 35,55 persen. Hasil penelitian ini menunjukkan pola yang sama dengan penelitian sebelumnya yang menyatakan bahwa pengeluaran terbesar pada usahatani bawang merah digunakan untuk benih dan tenaga kerja (Nurasa dan Darwis 2007; Asih 2009; Mayowani dan Darwis 2010; Purmiyati 2002). Perbedaan pada struktur biaya menunjukkan adanya perbedaan dalam penggunaan sarana produksi pertanian, perbedaan harga input dan perbedaan tingkat upah antar lokasi. Faktor kondisi alam seperti intensitas serangan hama dan penyakit atau kekeringan juga berpengaruh terhadap pengeluaran usahatani. Akan tetapi pola proporsi pengeluaran pada ketiga lokasi tersebut relatif sama yaitu proporsi terbesar untuk sarana produksi, kedua untuk tenaga kerja dan ketiga biaya lainnya. 
Haris F. A., Anna F., dan Netti T.: Analisis profitabilitas usahatani ...

Tabel 5. Struktur Biaya Usahatani Bawang Merah di Kabupaten Cirebon, Brebes dan Tegal Musim Tanam Tahun 2013-2014

\begin{tabular}{|c|c|c|c|c|c|c|c|c|}
\hline \multirow{3}{*}{ Kabupaten } & \multirow{3}{*}{ Musim } & \multicolumn{6}{|c|}{ Jenis Biaya } & \multirow{3}{*}{$\begin{array}{r}\text { Total } \\
\text { Rp } 000\end{array}$} \\
\hline & & \multicolumn{2}{|c|}{ Sarana Produksi } & \multicolumn{2}{|c|}{ Tenaga Kerja } & \multicolumn{2}{|c|}{ Biaya Lainnya } & \\
\hline & & $\mathrm{Rp} 000$ & $\%$ & $\mathrm{Rp} 000$ & $\%$ & $\mathrm{Rp} 000$ & $\%$ & \\
\hline \multirow[t]{3}{*}{ Cirebon } & MH & 42.874 & 61,10 & 22.280 & 31,75 & 5.010 & 7,14 & 70.166 \\
\hline & MK I & 41.872 & 59,34 & 23.911 & 33,89 & 4.780 & 6,77 & 70.563 \\
\hline & MK II & 42.182 & 58,04 & 24.708 & 34,00 & 5.781 & 7,96 & 72.673 \\
\hline \multirow[t]{3}{*}{ Brebes } & $\mathrm{MH}$ & 33.153 & 57,40 & 22.009 & 38,11 & 2.593 & 4,49 & 57.756 \\
\hline & MK I & 28.354 & 51,19 & 23.214 & 41,91 & 3.818 & 6,89 & 55.387 \\
\hline & MK II & 33.570 & 58,27 & 20.739 & 36,00 & 3.301 & 5,73 & 57.611 \\
\hline \multirow[t]{3}{*}{ Tegal } & $\mathrm{MH}$ & 40.949 & 63,80 & 22.046 & 34,35 & 1.190 & 1,85 & 64.186 \\
\hline & MK I & 30.298 & 61,36 & 17.356 & 35,15 & 1.723 & 3,49 & 49.378 \\
\hline & MK II & 33.120 & 61,95 & 18.606 & 34,80 & 1.733 & 3,24 & 53.460 \\
\hline
\end{tabular}

Sumber : PKHT, 2014 (Diolah)

Tabel 6. Profitabilitas Usahatani Bawang Merah di Kabupaten Cirebon, Brebes dan Tegal Musim Tanam Tahun 2013-2014

\begin{tabular}{|c|c|c|c|c|c|c|c|}
\hline \multirow{2}{*}{ Kabupaten } & \multirow{2}{*}{ Musim } & Produktivitas & Harga & Penerimaan & Total Biaya & Profitabilitas & \multirow{2}{*}{$\mathrm{R} / \mathrm{C}$} \\
\hline & & $(\mathrm{Kg} / \mathrm{ha})$ & $(\mathrm{Rp} / \mathrm{Kg})$ & $(\mathrm{Rp} 000)$ & $(\mathrm{Rp} 000)$ & $(\mathrm{Rp} 000)$ & \\
\hline \multirow[t]{3}{*}{ Cirebon } & $\mathrm{MH}$ & 10.263 & 7.795 & 80.001 & 70.166 & 9.835 & 1,14 \\
\hline & MK I & 12.085 & 9.357 & 113.081 & 70.563 & 42.518 & 1,60 \\
\hline & MK II & 12.739 & 9.440 & 120.250 & 72.673 & 47.577 & 1,65 \\
\hline \multirow[t]{3}{*}{ Brebes } & $\mathrm{MH}$ & 6.755 & 11.250 & 75.996 & 57.756 & 18.239 & 1,32 \\
\hline & MK I & 7.564 & 10.375 & 78.479 & 55.387 & 23.092 & 1,42 \\
\hline & MK II & 6.466 & 9.458 & 61.158 & 57.611 & 3.546 & 1,06 \\
\hline \multirow[t]{3}{*}{ Tegal } & MH & 7.289 & 13.071 & 95.272 & 64.186 & 31.085 & 1,48 \\
\hline & MK I & 8.695 & 8.500 & 73.907 & 49.378 & 24.528 & 1,50 \\
\hline & MK II & 8.594 & 9.057 & 77.837 & 53.460 & 24.377 & 1,46 \\
\hline
\end{tabular}

Sumber : PKHT, 2014 (Diolah)

Penerimaan usahatani bawang merah pada penelitian ini merupakan hasil kali dari jumlah bawang merah yang dijual petani dengan harga yang berlaku yang diterima petani. Bawang merah yang dihasilkan oleh petani ada beberapa yang disisihkan untuk benih. Oleh karena itu dalam penghitungan penerimaan, output bawang merah merupakan jumlah bawang merah yang dijual oleh petani.

Penerimaan usahatani bawang merah terbesar ada di Kabupaten Cirebon dengan ratarata penerimaan $\mathrm{Rp}$ 104.444.826/ha. Penerimaan usahatani tertinggi dicapai pada musim kemarau II dimana pada musim ini produksi yang dijual relatif lebih banyak dan harga jualnya relatif lebih tinggi dibandingkan dengan musim lainnya.
Penerimaan usahatani di Kabupaten Tegal merupakan terbesar kedua dengan rata-rata penerimaan sebesar Rp 82.339.174/ha. Penerimaan usahatani tertinggi dicapai pada musim hujan dimana pada musim ini produksi yang dijual relatif lebih sedikit dibandingkan dengan musim lainnya namun dengan harga jual yang jauh lebih besar.

Kabupaten Brebes memiliki rata-rata penerimaan yang lebih rendah dibandingkan dengan Kabupaten Cirebon dan Tegal. Rata-rata penerimaan usahatani di Brebes sebesar Rp 71.887.966/ha. Rendahnya penerimaan yang diperoleh petani di Kabupaten Brebes ini dikarenakan produksi yang dijual relatif lebih sedikit jika dibandingkan dengan Kabupaten Cirebon maupun Tegal. Penerimaan usahatani 
tertinggi dicapai pada musim kemarau I dimana pada musim ini produksi yang dijual relatif lebih banyak dibandingkan dengan musim lainnya dan harga jual juga cukup tinggi.

Rata-rata keuntungan usahatani yang diperoleh petani di Kabupaten Cirebon lebih besar dibandingkan dengan Kabupaten Brebes dan Tegal. Rata-rata keuntungan usahatani di Kabupaten Cirebon sebesar Rp 33.310.543/ha, di Kabupaten Tegal Rp 26.663.864/ha dan di Kabupaten Brebes Rp 14.595.694/ha. Perbedaan keuntungan di setiap daerah ini dikarenakan adanya variasi tingkat produktivitas, harga produk, dan biaya usahatani di masing-masing daerah.

Usahatani bawang merah pada musim hujan, musim kemarau I dan musim kemarau II secara umum semuanya menguntungkan. Ketiga lokasi memiliki pola yang berbeda. Keuntungan usahatani terbesar dicapai pada musim kemarau II untuk Kabupaten Cirebon, musim kemarau I untuk Kabupaten Brebes, dan musim hujan untuk Kabupaten Tegal. Kecenderungan di beberapa daerah lainnya menunjukkan bahwa keuntungan usahatani bawang merah terbesar dicapai pada musim kemarau. Hasil penelitian Widyantara dan Yasa (2013) menunjukkan bahwa pendapatan bersih petani bawang merah di Kintamani, Bali, pada musim hujan (Rp 11.557.860,39/ha) lebih kecil daripada musim kemarau (Rp 61.571.696,07/ha). Akan tetapi tingkat risiko yang dihadapi petani pada musim kemarau lebih besar daripada musim hujan. Hal yang sama juga ditunjukkan oleh Rachman et al (2004) yaitu keuntungan usahatani bawang merah di Indramayu dan Majalengka tertinggi dicapai pada musim kemarau II karenakan rata-rata produksi dan harga bawang merah pada musim kemarau II lebih tinggi dibanding musim lainnya.

Usahatani bawang merah di Kabupaten Cirebon, Brebes, dan Tegal secara finansial layak dan menguntungkan untuk diusahakan pada setiap musim. Nilai R/C yang diperoleh pada setiap musim menunjukkan lebih dari satu yang berarti penerimaan yang diperoleh lebih besar daripada biaya yang dikeluarkan. Akan tetapi nilai R/C yang diperoleh di ketiga lokasi penelitian tersebut masih mendekati satu. Hal ini mengindikasikan bahwa gejolak perubahan harga baik harga output maupun harga input akan sangat berpengaruh terhadap pendapatan usahatani petani bawang merah. Petani rentan mengalami kerugian apabila terjadi lonjakan harga input atau penurunan harga output.

\section{KESIMPULAN DAN SARAN}

\section{Kesimpulan}

Petani bawang merah di Kabupaten Cirebon, Brebes dan Tegal masih didominasi pada retang usia produktif yaitu usia 40-59 tahun. Sebagian besar pendidikan petani adalah sekolah dasar. Pengalaman bertani bawang merah petani di Kabupaten Brebes cukup lama yaitu 11-30 tahun sedangkan petani di Kabupaten Cirebon dan Tegal berkisar antara 1-10 tahun. Penguasaan lahan untuk usahatani bawang merah masih dibawah 0,5 hektar yang terdiri dari lahan milik sendiri maupun lahan sewa.

Pengeluaran usahatani di Kabupaten Cirebon relatif lebih tinggi jika dibandingkan dengan Kabupaten Brebes maupun Tegal. Rata-rata biaya usahatani yang dikeluarkan sebesar $\mathrm{Rp}$ 71.134.283/ha. Sementara itu, rata-rata biaya usahatani yang dikeluarkan di Kabupaten Brebes sebesar Rp 56.918.272/ha dan di Kabupaten Tegal sebesar Rp 55.675.310/ha.

Komponen pengeluaran terbesar dalam usahatani bawang merah adalah untuk pembelian benih dan upah tenaga kerja. Pengeluaran untuk benih berkisar antara 27,46-44,36 persen dengan rata-rata sebesar 37,80 persen. Pengeluaran untuk upah tenaga kerja berkisar antara 31,75-41,91 persen dengan rata-rata sebesar 35,55 persen.

Rata-rata keuntungan usahatani di Kabupaten Cirebon sebesar Rp 33.310.543/ha, di Kabupaten Tegal Rp 26.663.864/ha dan di Kabupaten Brebes Rp 14.595.694/ha. Usahatani bawang merah di Kabupaten Cirebon, Brebes, dan Tegal secara finansial layak dan menguntungkan untuk diusahakan pada setiap musim karena nilai $\mathrm{R} / \mathrm{C}$ yang diperoleh pada setiap musim menunjukkan lebih dari satu.

\section{Saran}

1. Dalam rangka peningkatan produksi maka pengembangan bawang merah diarahkan pada produksi di luar musim (off season) dengan cara perakitan varietas tahan musim hujan dan diseminasi varietas tahan musim hujan yang sudah ada.

2. Supaya pasokan bawang merah dalam negeri stabil maka perlu dibuat kalender tanam pada setiap daerah sentra dengan menyesuaikan agroekosistem dan musim serta saling terkoordiasi antara satu daerah dengan daerah yang lain.

3. Penting untuk dilakukan pembinaan dan pembentukan penangkar benih bersertifikat 
Haris F. A., Anna F., dan Netti T.: Analisis profitabilitas usahatani ...

yang lebih banyak untuk menghasilkan pasokan benih yang lebih banyak, kontinu, dan berkualitas untuk mengatasi kelangkaan ketersediaan benih dan mengatasi lonjakan harga benih pada musim-musim di luar tanam.

\section{DAFTAR PUSTAKA}

Asih DN. 2009. Analisis karakteristik dan tingkat pendapatan usahatani bawang merah di Sulawesi Tengah. J. Agroland 16(1): 5359.

Asmara R dan Ardhiani R. 2010. Integrasi pasar dalam sistem pemasaran bawang merah. AGRISE 10(3): 164-176

Basuki RS. 2009a. Analisis tingkat preferensi petani terhadap karakterisitik hasil dan kualitas bawang merah varietas lokal dan impor. J. Hort. 19(2):237-248.

2009b. Pengetahuan petani dan keefektifan penggunaan insektisida oleh petani dalam pengendalian ulat Spodoptera exigua Hubn. pada tanaman bawang merah di Brebes dan Cirebon. $J$. Hort. 19(4):459-474.

2010. Sistem pengadaan dan distribusi benih bawang merah pada tingkat petani di Kabupaten Brebes. J. Hort. 20(2):186-195.

[BPS] Badan Pusat Statistik. 2013. Perkembangan indeks harga konsumen/inflasi. Berita Resmi Statistik No 48/08/Th. XVI, 1 Agustus 2013. Jakarta (ID) : Badan Pusat Statistik.

Darwis V, Irawan B, Muslim C. 2004. Keragaan Benih Hortikultura di Tingkat Produsen dan Konsumen (Studi Kasus : Bawang Merah, Cabai Merah, Kubis, dan Kentang). SOCA 4(2): 1-18

[Deptan] Departemen Pertanian. 2005. Prospek dan Arah Pengembangan Agribisnis Bawang Merah. Jakarta (ID) : Departemen Pertanian.

Dinas Pertanian Tanaman Pangan dan Hortikultura Kabupaten Brebes. 2011. Standar Operasional Prosedur Budidaya Bawang Merah (Allium ascalonicum L.) Kabupaten Brebes Provinsi Jawa Tengah. Brebes (ID) : Dinas Pertanian Tanaman
Pangan dan Hortikultura Kabupaten Brebes.

[Kemendag] Kementerian Perdagangan. 2015. Tabel Harga Pokok Kebutuhan Nasional. Diakses

di http://www.kemendag.go.id/id/economicprofile/prices/national-price-table pada hari Selasa, Tanggal 20 Januari 2015 Pukul 11.00 WIB

Nurasa T dan Darwis V. 2007. Analisis usahatani dan keragaan marjin pemasaran bawang merah di Kabupaten Brebes. Jurnal Akta Agrosia 10(1): 40-48.

Mayrowani H dan Darwis V. 2010. Perspektif pemasaran bawang merah di Kabupaten Brebes, Jawa Tengah. Di dalam: Suradisastra K, Simatupang P, Hutabarat B, editor. Prosiding Seminar Nasional Peningkatan Daya Saing Agribisnis Berorientasi Kesejahteraan Petani; 2009 Okt 14; Bogor, Indonesia. Bogor (ID) : PSEKP. hlm 169-186.

Moekasan TK, Basuki RS. 2007. Status resistensi Spodoptera exigua Hubn. pada tanaman bawang merah asal Kabupaten Cirebon, Brebes, dan Tegal terhadap insektisida yang umum digunakan petani di daerah tersebut. J. Hort. 17(4):343-354

Natawidjaja R.S. 2007. Pengembangan komoditas bernilai tinggi (high value commodity) untuk meningkatkan pendapatan petani. Di dalam: Suradisastra K, Yusdja Y, Hutabarat B, editor. Prosiding Seminar Nasional Dinamika Pembangunan Pertanian dan Pedesaan : Mencari Alternatif Arah pengembangan Ekonomi Rakyat. 2007 Desember 04; Bogor, Indonesia. Bogor (ID) : PSEKP. hlm 17-29.

Putrasamedja S. 2010. Pengujian beberapa klon bawang merah dataran tinggi. Jurnal Pembangunan Pedesaan 10(2) : 86-92.

Purba R, Astuti Y. 2013. Paket teknologi bawang merah di luar musim tanam di Pandeglang Banten. AGRITECH 15(2) : 105-113.

Purba R. 2014. Produksi dan keuntungan usahatani empat varietas bawang merah di luar musim (off -season) di Kabupaten Serang, Banten. Agriekonomika 3(1) : 5564 
Haris F. A., Anna F., dan Netti T.: Analisis profitabilitas usahatani ...

Purmiyati S. 2002. Analisis produksi dan daya saing bawang merah di Kabupaten Brebes Jawa Tengah [tesis]. Bogor (ID): Institut Pertanian Bogor.

[Pusdatin] Pusat Data dan Informasi Pertanian. 2013. Outlook Bawang Merah. Jakarta (ID) : Departemen Pertanian.

Rachman HPS, Supriyati, Saptana, Rachman B. 2004. Efisiensi dan daya saing usahatani hortikultura. Di dalam: Saliem HP, Basuno E, Sayaka B, Sejati WK, editor. Efisiensi dan Daya Saing Sistem Usahatani Beberapa Komoditas Pertanian di Lahan Sawah. Bogor, Indonesia. Bogor (ID) : PSEKP. hlm 50-82.

Sayaka B, Supriatna Y. 2010. Kemitraan pemasaran bawang merah di Kabupaten Brebes, Jawa Tengah: kasus PT Indofood
Sukses Makmur. Di dalam: Suradisastra K, Simatupang P, Hutabarat B, editor. Prosiding Seminar Nasional Peningkatan Daya Saing Agribisnis Berorientasi Kesejahteraan Petani; 2009 Okt 14; Bogor, Indonesia. Bogor (ID) : PSEKP. hlm 187-201.

Widyantara W, Yasa NS. 2013. Iklim sangat berpengaruh terhadap risiko produksi usahatani bawang merah (Allium ascalonicum L). E-Jurnal Agribisnis dan Agrowisata 2(1): 32-37.

Winarso B. 2003. Dinamika perkembangan harga: hubungannya dengan tingkat keterpaduan antarpasar dalam menciptakan efisiensi pemasaran komoditas bawang merah. Jurnal Ilmiah Kesatuan 4(1): 7-16. 